\title{
Ekspansi Kompeni Hingga Sanad Kiai-Santri: Sejarah Islamisasi Ujung Timur Pulau Jawa Abad XVII-XX
}

\author{
Arif Subekti \\ Universitas Negeri Malang
}

\begin{abstract}
This study aims to examine the history of islamization missionary in Banyuwangi, Eastern Java from $17^{\text {th }}$ century to 20th century. This study identifies the agent of islamization, motive, model of dakwah, as well as narrating the attitude and form of acceptance of the Banyuwangi communities. This study deals with historical approach to gain the answer of the research questions, and uses the primary and secondary data such as archives, oral sources, and some relevant references. The conclusions of this study are; first, the Eastern Java was the last section region of islamization in Java; second, the collaboration of colonial power and the Kingdom of Mataram played important role in islamization process; third, the depopulation has direct relation toward islamization and domination of Java and Madura ethnicity; fourth, the chain of islamic scientific and teacher-students relationships describe the teacher-student lines of islamization.
\end{abstract}

\begin{abstract}
Abstrak
Penelitian ini bertujuan untuk meneliti sejarah islamisasi di Banyuwangi, Jawa Timur dari abad ke- 77 sampai abad ke-20. Penelitian ini mengidentifikasi agen islamisasi, motif, model dakwah, serta menceritakan sikap dan bentuk penerimaan masyarakat Banyuwangi. Penelitian ini membahas pendekatan historis untuk mendapatkan jawaban dari pertanyaan penelitian, dan menggunakan data primer dan sekunder seperti arsip, sumber lisan, dan beberapa referensi yang relevan. Kesimpulan dari penelitian ini adalah; Pertama, Jawa Timur merupakan daerah bagian terakhir dari islamiisasi di Jawa; Kedua, kolaborasi kekuasaan kolonial dan Kerajaan Mataram memainkan peran penting dalam proses islamisasi; Ketiga, depopulasi memiliki hubungan langsung dengan islamiisasi dan dominasi etnis Jawa dan Madura; Keempat, rantai hubungan islami dan guru-siswa islami menggambarkan jalur islamisasi guru-siswa.
\end{abstract}

Keywords: Islamization, Colonialization, Sanad, Banyuwangi

DOI: 10.22515/shahih.v2i1.686

Coressponding author

Email: anugerah9langit@gmail.com 


\section{Pendahuluan}

Pembahasan Islamisasi dalam arti luas yang tidak hanya dimaknai sebatas konversi kredo keimanan melainkan meliputi pula proses penegakan ritus-ritus serta norma agama Islam, tidak selesai pada penelusuran perihal asal muasal, kala persebaran, dan siapa kelas muballigh-nya. Islamisasi yang melibatkan agen-agen penyebar misi dakwah yang kemudian diidentifikasi sebagai ulama, berikut derivasi penyebutannya, terjadi bahkan hingga sekarang. Makna perjuangan Islamisasi meluas, dari lingkup memimpin santri, menerjemahkan ayat suci, teks perihal tradisi di masa kenabian, serta literatur yurisprudensi hukum Islam ( $f i q h$ ) di pesantren dan madrasah, atau menjadi imam salat di masjid, surau, langgar, dan musala belaka; kemudian berkembang dalam lingkup menyandang posisi strategis di organisasiorganisasi kemasyarakatan, jabatan pemerintahan, serta partai politik.

Peran ulama tingkat lanjut paska kolonial ialah menjembatani cita-cita para aktivis nasionalis kerah putih dan massa rakyat. Upaya membangun negara persatuan Indonesia merdeka sesuai dengan garis pandu manajerial negara ala Barat ini, bertumbukan dengan massa rakyat terdiri dari para petani di Jawa, Sunda, Aceh, Bugis, dan wilayah budaya lainnya. Kelompok terakhir ini lebih lekat pada pola organisasi komunitas lokal serta lebih percaya pada apa yang dekat dengan kehidupan sehari-hari mereka. Inilah yang ditalangi oleh ulama tingkat lanjut. Dengan meminjam konsep (Geertz, 1960; Wolf, 1956) menyebut peran baru ulama ini sebagai cultural broker.

Tulisan ini memaparkan gambaran umum Banyuwangi sebagai panggung sejarah dari penelitian ini. Sebagai langkah awal, diuraikan komposisi etnis setelah depopulasi besar-besaran. Kemudian dipaparkan mitos Islamisasi atas Blambangan berikut kedatangan para migran beragama Islam, yang mewujud dalam polarisasi masyarakat, aneka bentuk organisasi, serta karakter dari masing-masing kelompok. Dibentangkan pula pesantrenpesantren berpengaruh di Banyuwangi sesuai dengan kurun masa penelitian ini, beserta jalinan genealogi intelektual yang secara tidak langsung mencerminkan hubungan gurumurid.

\section{Banyuwangi: Latar Historis, Sosiologis, dan Budaya}

Jawa Timur, sebagai propinsi paling padat penduduk se-Indonesia, secara kultural sangat heterogen. Bagian paling timur dari propinsi ini, jamak disebut sebagai daerah tapal kuda, yang membentang sepanjang Besuki hingga Jember, meliputi Lumajang, Situbondo, Bondowoso, serta Banyuwangi. Di wilayah ini, khususnya Banyuwangi, seperti yang diteliti Caroline Campbell dan Linda H. Connor laju urbanisasi dan kerapatan populasi yang sangat tinggi menjadi permasalahan ekologis semenjak masa kekuasaan kolonial. Secara ekonomi, dibandingkan Jember dan Lumajang, Banyuwangi merupakan pusat jaringan migrasi 
produksi manufaktur di antara ketiga mata rantai pertanian dan lumbung padi terbesar di wilayah tapal kuda tersebut (Mackie, 1993, pp. 23-53).

Kecamatan Kota Banyuwangi, yang dahulu kala merupakan ibukota Kerajaan Blambangan, dijadikan pusat dari pemerintahan Residensi Belanda Blambangan Timur. Sejak 1881 (tahun 1826 menurut Lekkerkerker dalam (Wolbers, 1986, p. 75) Afdeling Banyuwangi yang wilayahnya seluas $3.780 \mathrm{~km}$ persegi dimasukkan dalam Keresidenan Besuki, dan dibagi dalam tiga distrik. Distrik Banyuwangi yang terletak di bagian paling utara, Distrik Rogojampi, dan Distrik Genteng (Encylopaedie van Nederlandsch-Indie, 1917), setelah pada tahun 1849 Pemerintah Kolonial Belanda menjadikannya pusat dari satu distrik baru, bernama Banyuwangi, dari sini Belanda menjalin hubungan dengan Bali dan Lombok. Selanjutnya, pada tahun 1882, Banyuwangi menjadi ibukota dari Residensi Besuki yang mencakup bagian ujung timur Jawa, yang kurang lebih mencerminkan teritori Blambangan kuno (Wolbers, 1986). Pada sensus 1930, Regensi Banyuwangi dibagi atau terdiri atas empat distrik, ditambah dengan Cluring (Volkstelling, 1930, p. 69).

Di sisi lain, depopulasi yang mendera seluruh Jawa pada umumnya, dan Blambangan pada khususnya, yang di antaranya disebabkan oleh peperangan, kelaparan, dan wabah penyakit, berbuntut pada percampuran dan persebaran etnis yang cukup variatif di Banyuwangi. Beatty berasumsi bahwa orang Osing adalah keturunan dari sisa orangorang Blambangan setelah Perlawanan Wilis dan Rempeg tahun 1761-1768 dan 1771-1773 (Beatty, 2004, p. 11). Sementara orang-orang Jawa, alias wong kulonan (Arps, 2009, p. 9) dan Madura sebagai dua etnis pendatang terbesar, didatangkan terutama setelah pemerintahan wilayah Blambangan dapat dikontrol oleh penguasa kolonial. Kedatangan mereka, terutama dilatarbelakangi oleh kenyataan depopulasi serta perihal bagaimana tanah yang berhasil diduduki tersebut dapat diekspolitasi sebaik mungkin bagi keuntungan ekonomi kolonial.

Para pendatang memiliki peranan yang besar dalam proses Islamisasi Blambanganuntuk tidak menyebut santrinisasi-terutama sekali pada masa setelah depopulasi atau sejak abad ke-19. Wong kulonan, yakni orang-orang Mataraman, Madura, Bugis, Mandar, Melayu, hingga Banten dalam berbagai perannya (buruh perkebunan, pedagang, buangan politik, dan ragam perkerjaan migran lain) selain bermukim dan menjadi orang Banyuwangi, pun menyebarluaskan budaya dan agama Islam. Memang tidak bisa dipastikan, faktor apa serta seberapa cepat perkembangan Islamisasi di Banyuwangi. Namun, semakin mapannya pemerintahan kolonial di wilayah ini, diikuti pula dengan hadirnya hierarki administrasi keislaman, meneguhkan bahwa Islamisasi Banyuwangi telah dan tengah dilaksanakan. Seorang dokter berkebangsaan Jerman yang mengunjungi Banyuwangi pada awal abad ke-19 melaporkan bahwa telah terdapat seorang 'pendeta tinggi' (penghulu) berserta staf pembantunya, yang diupah dengan pajak tanah pemasukan tertentu dalam memimpin upacara pernikahan, serta 10\% dari 1/10 pajak hasil panen penduduk (Beatty, 2004, 
pp. 15-16). Epp, nama dokter ini, menggarisbawahi bahwa 'pendeta tinggi' beserta para pembantunya tersebut tidak memiliki pengaruh yang berarti dalam masyarakat, kecuali pada penuaian kewajiban dan penerimaan hak kedinasan sebagaimana telah terpaparkan di atas. Ia juga menyatakan bahwa jejak-jejak agama tua (Hindu) masih banyak ditemukan saat itu (Wolbers, 1993, p. 53).

Namun demikian, "nilai-nilai Islam" yang tercermin dalam sikap penduduk, seperti keyakinan akan sakralitas Nisfu Sya'ban tiap tanggal 15 Ruwah-termasuk penggunaan kalender Islam produk Sultan Agung tersebut_-serta rendahnya pengiriman anak perempuan dalam dunia pendidikan, khususnya di Banyuwangi untuk pendidikan kebidanan misalnya, diyakini berbanding lurus dengan ajaran Islam yang melarang para gadis pergi ke sekolah (Hesselink, 2011, p. 132). Kesalehan Islam yang dipraktikkan oleh para migran dengan membawa dan mengembangkan Islam di Banyuwangi, lantas mencerminkan Banyuwangi sebagai tempatnya 'kaum sederhana dan saleh, hidup' (Pijper, 1992, pp. 5-23). Kendati bahwa para migran ini bisa jadi tidak membaiat orang menjadi Islam (orang Osing), melainkan sekadar meningkatkan kesalehan diri.

Depopulasi paska pergolakan Wilis dan Rempeg, membuat penguasa kolonial mengeluarkan pelbagai kebijakan strategis guna menghadirkan kembali para pekerja dalam rangka memulihkan kehidupan ekonomi Banyuwangi: wanita dan anak-anak dihalangi untuk bermigrasi, sebaliknya orang-orang Jawa dari wilayah sekitar, serta orang-orang Cina dari Batavia didorong untuk menempati wilayah yang nyaris kosong ini, pun pekerja seks komersial dikarya-ciptakan, bahkan orang-orang perantean (tahanan politik) dibuang di sini.

Namun, restorasi kehidupan ekonomi ini baru bisa dianggap menuai hasil manakala orang-orang Madura mulai menetap di sepanjang pantai utara Keresidenan Besuki, dan dari sana menyebar ke wilayah Jember, Bondowoso, serta Banyuwangi bagian barat. Mereka dipersiapkan sebagai buruh-buruh perkebunan yang banyak dibuka oleh penguasa kolonial (Wolbers, 1993, p. 57).

Hingga awal abad ke-20, mobilisasi penduduk ke daerah Banyuwangi dikatakan tertinggi di antara kabupaten-kabupaten se-Jawa (Beatty, 2004). Selain kebijakan kolonial di atas, dalam mendorong restorasi kehidupan ekonomi, pembangunan rel kereta api yang menghubungkan Kalisat-Banyuwangi dengan seluruh Jawa pada 1903, dalam waktu yang relatif singkat telah mampu menarik migrasi besar-besaran untuk menempati wilayah tersebut. Gelombang migrasi ini didominasi oleh wong kulonan, yang sebelumnya didominasi orang-orang Madura. Tak pelak, pembangunan rel kereta telah menarik kuli-kuli wilayah Jawa sebelah barat (Wolbers, 1992, p. 56). Perkembangan lain adalah bahwa adanya jalur kereta api juga berperan dalam pembukaan dan pengelolaan hutan belantara menjadi sawah dan perkebunan (van Gent dalam Wolbers, 1992). Sensus pertama 1930 kemudian 
membuktikan bahwa 47,2 \% penduduk Banyuwangi lahir di luar daerah (van Gent dalam Wolbers, 1992).

Secara umum, gambaran persebaran etnis di Banyuwangi selama dan setelah migrasi ini adalah, 'orang-orang asli'-berdialek Osing-menempati areal tertentu; dataran tinggi di sekitar pendopo residen atau pusat pemerintahan, yakni Giri dan Glagah; Kabat dan Rogojampi di sebelah selatan; dan sisanya di Genteng dan Srono. Selain dialek, perbedaan dengan orang Jawa adalah kulit mereka yang lebih terang, relatif kebal terhadap penyakit, sifatnya yang polos membuat mereka mudah diperdaya orang Madura (Epp dalam Wolbers, 1992). Nelayan Bugis dan Mandar berada di pesisir wilayah pantai timur sekitar Ulupampang, Muncar, Tegaldlimo, dan pantai utara, yang beragama Islam, nelayan ulung, dan gemar berjudi. Sekelompok kecil nelayan Cina juga menempati pesisir timur Kota sepanjang rawa beserta kompatriotnya yang berdagang; mereka membangun sebuah pagoda dengan patung yang dihormati orang Cina di seluruh Jawa serta dipercaya sebagai yang tertua di Jawa. Pesaing orang Cina adalah muslim Arab yang tinggal di pusat-pusat kegiatan transaksi ekonomi. Tenaga buruh perkebunan dari Madura terkonsentrasi di sebelah barat laut dan selatan. Sementara orang Jawa menempati wilayah-wilayah dataran rendah sebagai penggarap sawah. Epp (tahun 1840-an tinggal di Banyuwangi) menggambarkan persebaran etnis di Distrik Banyuwangi, di mana orang-orang Bali tinggal di daerah yang terpisah dengan etnis lainnya karena agama mereka yang berbeda, dipimpin oleh seorang gusti, hidup di perkampungan yang kecil dan kumuh (Beatty, 2004, p. 17).

\section{Islamisasi Banyuwangi}

Pembahasan mengenai tempat asal datangnya budaya dan agama Islam ke Nusantara adalah suatu hal yang panjang, rumit, dan paling tidak jelas (Ricklefs, 2001, p. 3). Wujud dari ketidakjelasan tersebut di antaranya adalah jurang yang dalam antara zaman Hindu-Jawa dengan zaman Islam, bahwa seolah-olah peradaban Hindu-Jawa yang direpresentasikan Majapahit tiba-tiba lenyap, lantas sekonyong-konyong berdiri peradaban Islam Demak (de Graaf, 1989, p. 3). Ketidakjelasan ini kian terang-terang laras saja, dengan adanya legendalegenda terkenal mengenai orang-orang sakti pendatang atau keturunannya, alias orang lokal yang memiliki galur genenalogi dengan elit penguasa lama yang telah memberai-beraikan agama Islam di pulau Jawa pada abad ke-15 dan ke-16, lantas populer dengan sebutan 'Wali Songo' (Sutrisno 2004, Sunyoto 2011, 2012).

Demikian pula, menelusuri secara akurat dan rinci perihal awal mula Islamisasi Banyuwangi meskipun hal yang tidak mustahil, namun bukan pekerjaan mudah, serta tiadalah titik utama penelitian ini. Legenda yang acapkali terbit perihal penetrasi Islam di wilayah ini adalah kisah Syeh Walilanang alias Molana Iskak/Maulana Ishaq, yang dituturkan 
sebagai ayah dari Joko Samudro alias Sunan Giri, salah satu dari sembilan orang suci atau wali penyebar Islam di tanah Jawa. Dikisahkan bahwa Dewi Sekardalu/Sekardadu, putri penguasa Blambangan (Arifin, 1995), menderita sakit yang tak kunjung sembuh, sehingga diadakanlah sayembara; barang siapa yang sanggup menyembuhkan penyakit putri, akan diambil menantu raja. Ada tafsir bahwa penyakit yang kemudian berhasil disembuhkan oleh Walilanang adalah 'kekafiran', dalam arti penyakit sang putri dapat disembuhkan oleh seorang yang dekat dengan Tuhan (makna leksikal wali adalah kekasih, maka frase waliyullah bermakna kekasih atau orang yang dekat dengan Allah). Manakala sang wali pergi, maka segera saja wabah penyakit agama lama/kekafiran-tersebut kambuh kembali (Arifin, 1995). Legenda ini, secara tersirat hendak memberikan pengertian bahwa Islamisasi yang dilaksanakan pada masa tersebut menemui jalan. Ricklefs bahkan menilai, kisah ini sebagai satu-satunya legenda Islamisasi Jawa dengan adegan-adegan supranatural yang gagal (Ricklefs, 1993).

Tradisi tutur kedua, adalah cerita Jawa-Bali yang tertuang dalam Babad Pamancangah Bali, yang mengisahkan seorang putri Blambangan yang karena menolak untuk menjadi istri Raja Batu Renggong dari Gelgel telah menyebabkan terjadinya perang antara ayahnya dan raja Bali itu. Ia dapat lolos dari Raja Batu Renggong berkat bantuan salah seorang saudaranya lain ibu, bernama Bima Cili (Buyut Cili di Kemiren). Mereka bersama telah melarikan diri ke Pasuruan, yang pada pertengahan abad ke-16 Islam merupakan agama utama di sana, dan raja-raja Pasuruan bermusuhan dengan raja-raja Blambangan. Oleh karena itu, dapat dimengerti jika cerita tutur Bali ini berdasarkan peristiwa sejarah, bahwa penolakan putri Blambangan dan pengungsiannya kemudian ke Pasuruan yang beragama Islam itu ada hubungannya dengan pertentangan antara "kekafiran/heidendom" dan Islam (de Graaf, 1989, p. 242).

Sementara, karya akademik mengenai Islamisasi di ujung timur Pulau Jawa secara umum, yang ditulis De Graaf dan Pigeaud, menggambarkan bahwa Islamisasi di wilayah ini sejatinya tidak terbaca jika menempatkan para pendakwah dan missi agama sebagai penentu. Justru faktor ekonomi yang mewujud dalam aktivitas perdagangan dan ekspansi kekuatan-kekuatan lokallah yang lantas ditunggangi proses penyebaran Islam (de Graaf, 1989). Margana melanjutkan, bahwa bukan hanya tidak serupa dengan wilayah di sekitarnya, Banyuwangi dapat digolongkan sebagai wilayah Islamisasi yang paling akhir di tanah Jawa. Bukannya roh atau spirit juang melawan kolonialisme, Islam dan Islamisasi dari Jawa dan Madura justru memainkan peran sentral dalam ekspansi Belanda di wilayah ini (de Graaf, 1989, p. 316). Hal ini tentu saja menarik, mengingat masyarakat bahkan sampai sekarang, sangat berterimakasih pada Islam. Berikut institusi yang dilekatkan dengan corak Islam, pesantren, ulama, haji, santri, dan sebagainya dengan menempatkannya sebagai pelopor perlawanan terhadap kolonialisme bangsa Barat (Bolland, 1982, p. 15). 
Islamisasi awal di Banyuwangi menempuh dua penjuru, yakni dari bawah yang tokohnya adalah masyarakat jelata, serta dari atas yakni kelas elit penguasa sebagai agennya. Kategori pertama, di antaranya dibuktikan dengan adanya catatan Kompeni mengenai desa Islam yang bernama Pagon, sebuah satuan kampung di dekat kota, ibu kota lama Blambangan yang dibakar dan penduduknya dibunuh sebagai ekses mundurnya prajurit Kompeni dalam pertempuran pertama melawan pasukan Agong Wilis pada 18 Pebruari 1768 (de Graaf, 1989). Adanya makam muslim kuno, seperti yang ada di daerah Wongsorejo dari abad ke-15 serta makam seorang tokoh bernama Datuk Ibrahim di Lateng yang dipercaya berasal dari Palembang dan hidup pada abad ke-18; juga turut menjadi bukti Islamisasi gugus bawah. Berdasarkan keterangan tutur dari Bapak Suhalik, para santri kelana, orang-orang perantean (tahanan atau buangan politik), para pedagang, dan migran lainnya termasuk dalam kategori ini.

Kelompok kedua, meliputi ekspansi politik yang dilakukan baik oleh kekuatan lokal seperti Mataram, kekuatan Kompeni Belanda, serta konversi kepada Islam dari para elit istana Blambangan. Mataram yang sejak masa pemerintahan Sultan Agung mencoba menjajah Blambangan, tidak sanggup secara paripurna menaklukannya. Sementara Kompeni dengan sumber daya yang lebih baik, mampu menancapkan hegemoni sekaligus menerapkan kebijakan Islamisasi atas Blambangan. Adapun di antara deretan nama kalangan istana yang dapat ditempatkan dalam rantai Islamisasi gugus atas adalah Pangeran Adipati Mancanapura atau Pangeran Macan Putih (memerintah 1691-1698), yang dalam pelariannya dari usaha kudeta dari kedua kemenakannya Mas Purba dan Mas Patih, putra Pangeran Adipati Sasranagara ke Pasuruan diberitakan telah beralih pada agama Islam (Margana, 2012, p. 39). Kemudian kisah Pangeran Adipati Danuningrat/Mangkuningrat/Pangeran Pati (memerintah 1736-1763) yang dibunuh di Seseh Bali, dan mayatnya bukannya dibakar melainkan dikubur. Juru kunci dari makam tersebut sampai sekarang, meskipun beragama Hindu, namun tidak mengonsumsi daging babi. Selain itu, karakteristik Islami dalam makam, seperti tulisan Arab di batu nisan dan orientasi arah hadap, makin memperkuat keyakinan bahwa Danuningrat tertarik atau sudah masuk agama Islam (Ibid, 139-143). ${ }^{1}$

Kecuali menafsirkan bahwa penyebaran epidemi yang dibawa Danuningrat ke komunitas Hindu-Bali merupakan metafora simbolis dari Islamisasi. Margana juga berasumsi bahwa pada masa terjadinya krisis politik di Blambangan, Islam sekali lagi diperkenalkan ke istana oleh beberapa anggota elite istana. Misalnya perkawinan dengan penguasa lokal sekitar yang telah memeluk Islam, yakni Bagus Lumajang dan Bagus Banger yang masingmasing pernah menikahi Mas Ayu Tawi (saudari tertua Danuningrat). Selain itu, kebijakan politik dari pihak Kompeni untuk mengislamkan Banyuwangi, bertujuan untuk meredam pemberontakan, sebagaimana yang dirasakan oleh Sutanagara (memerintah 1768-1771) (Ibid, 143, 147, 165). 
Hingga abad ke-18, bagian barat Blambangan sudah mulai menerima Islam, namun bagian timurnya masih memeluk agama Hindu. Kedua wilayah ini kemudian dipisahkan secara administratif oleh penguasa kolonial, dengan batas-batas alamiah, yakni Gunung Raung yang memanjang dari Sentong (Bondowoso) di utara hingga ke pantai selatan. Alasan otoritas kolonial dalam reorganisasi administratif tersebut, terutama adalah kepentingan suksesi kepemimpinan. Segregasi agama antara Blambangan bagian barat dan timur, dinilai menentukan tiap-tiap karakteristik kultural: Islamnya penduduk Blambangan Barat dikaitkan dengan sikap mereka yang lebih mudah diatur dan setia pada Kompeni, berbanding terbalik dengan penduduk Blambangan Timur yang Hindu sehingga bertabiat liar, atau berpotensi memberontak (Ibid, 214).

Blambangan memang telah menjadi benteng pertahanan dari ekspansi kekuatan kolonial serta Islamisasi, bagi Bali dan Hindu (Rouffaer dan Ijezman dalam Wolbers, 1992). Islamisasi awal penduduk Blambangan, dalam penelitian Margana menyimpulkan bahwa kolaborasi antara kekuatan Islam Jawa yakni Sunan, Sultan serta Panembahan Madura dengan penguasa kolonial dalam rangka menciptakan hegemoni politik di bumi Blambangan, telah berhasil mengeliminasi elemen Hindu-Bali (Margana, 2012, pp. 316-318). Kesimpulan bahwa Islamisasi menunggangi ekpansi politik kolonial, yang 'kafir' tentu menyentak narasi populer, bahwa Islamisasi Blambangan adalah hasil usaha dakwah oleh para wali, atau penaklukan oleh Mataram Islam, maupun hubungan perdagangan dengan orang-orang asing muslim.

Namun demikian, Islamisasi di Banyuwangi dalam arti sempit, berupa konversi agama khususnya bagi 'penduduk asli', tidak pernah terjadi hingga setelah pembunuhan beberapa perwira tinggi militer di Jakarta tahun 1965. Hingga masa ini pula, setidaknya polarisasi dan politisasi masyarakat berdasarkan dan terhadap Islam, mencapai titik dinamikanya yang tinggi. Orang-orang Jawa pendatang dengan persebaran yang sangat tinggi di hampir seluruh dataran rendah, membawa serta pengaruh baik ke-Jawa-an maupun keislamannya. Selanjutnya orang-orang Madura sebagai pendatang kedua terbanyak setelah wong kulonan di Banyuwangi, lebih menampakkan karakter Islam pesisir, sebagaimana wilayah-wilayah kantung etnis Madura di ujung timur Jawa. Sementara orang-orang Osing, sebagai 'penduduk asli' memiliki kenangan dan cara pandang atas Islam sebagai bagian dari budaya luar yang memberi pengaruh atas mereka, oleh karenanya wajar diwujudkan dalam ritual-ritual sinkretis.

Orang-orang Osing seperti yang diterangkan oleh (Arps, 2009, p. 9) tidak diperbedakan dalam kategori antara putihan dan abangan; melainkan istilah wong Islam yang diperbedakan bukannya dipertentangkan dengan istilah wong Jawa. Istilah pertama ditujukan oleh orang Jawa kepada orang yang beragama Islam dan menganggap agama tersebut bukan bagian dari ke-Jawa-annya. Istilah kedua ditujukan oleh seorang santri kepada tetangganya yang tidak menjalankan kewajiban agamanya dengan taat (Beatty, 2004, p. 126). 
SementarabagiwongKulonan, pembelahannya dapatberwujud santriyangdiperbedakan dengan abangan, atau nasional, terutama masa setelah perang. Santri (Geertz, 1980) berarti mereka yang melaksanakan rukun-rukun dalam agama Islam, menghindari ma lima, lima pantangan yang harus dihindari: maling-mencuri, madon-bermain perempuan dalam arti hubungan badan di luar nikah, madat-menghisap opium, main-berjudi, dan minummengonsumsi minuman beralkohol. Serta mempersiapkan atau menyediakan pendidikan agama bagi anak-anak mereka, membaca karya-karya berbahasa arab dan mendiskusikan beragam permasalahan dalam dunia Islam. Menurut Geertz, setidaknya ada tiga makna istilah santri, 1) term untuk orang yang tinggal di pesantren sebagai institusi pendidikan yang dipimpin seorang kiai, jika dihubungkan dengannya; 2) golongan yang diasosiasikan dengan pedagang, artinya bisa pengembara jika dihubungkan dengan kecenderungan aspek ekonomi yang dijalani, atau dengan salah satu saluran Islamisasi. Pada beberapa kasus, pesantren menjadi saluran besar dari penetrasi budaya perdagangan di daerah pesisir kepada kehidupan pedesaan di pedalaman; 3) pendukung dari partai berhaluan Islam dalam iklim politik aliran. Geertz. "the Javanese Kijaji: the Changing Role of a Cultural Broker". (Geertz, 1960) Kaum pertama ini, dipimpin atau menyandarkan kepemimpinan keagamaan dan seringkali juga kepemimpinan sosial politiknya pada seorang yang diidentifikasi sebagai ulama.

Dunia para santri atau wong Islam berbeda dengan dunia orang-orang nasional atau wong Jawa, mereka lebih berada atau mapan secara ekonomi, berpakaian lebih rapi dan bersih, lebih santun dalam tindak-tanduk, dan aktif dalam bisnis. Tuhan, menurut pemahaman para santri, tidak melarang atau membatasi hambanya untuk menumpuk harta, memiliki tanah luas, memperindah hunian tempat tinggal dan bangunan ibadah. ${ }^{2}$ Hampir merupakan nilai umum, bahwa sebuah keluarga santri mengambil menantu dari kelompok yang sama, dan perkawinan antar keluarga kiai $^{3}$ adalah hubungan besan yang ideal menurut cara pandang mereka. Idealitas ini lebih banyak dipengaruhi oleh posisi kiai dan keluarganya sebagai elit sosial dalam stratifikasi masyarakat, daripada misalnya kebiasaan menikahi saudara sedatuk (Dhofier, 1980, pp. 50-51).

Sementara wongJawa, yakni orang-orang abangan atau nasional, meskipun menjalankan beberapa aktivitas atau praktik religius tertentu, namun lebih didasari solidaritas sosial alihalih upaya pemenuhan kesalehan. Mereka lebih akrab dengan pagelaran tradisional seperti gandrung, seblang, wayang, atau hiburan-hiburan. Bahkan pada tahun 1960-an, lahir budaya kuntulan, sebuah seni perkusi dan lagu-lagu hadrah dan rebana, sebagai bandingan dari kelompok pertunjukan angklung dari orang-orang abangan (Anoegrajekti, n.d.), lain di mana kekuatan spiritual nenek moyang diperhatikan (Beatty, 2004, p. 245). Secara ekonomi, kelompok aliran ini relatif tidak memiliki kapital sebesar yang dimiliki oleh kaum santri; atau ketidakpunyaan faktor produksi yang pada tahun 1964-1965 menjadi alasan obyektif adanya 
aksi sepihak ${ }^{4}$ di daerah-daerah Banyuwangi. ${ }^{5}$

Perihal orang-orang abangan komunis, ditemukan keterangan bahwa pada 12 November tahun 1926, terdapat perlawanan lokal terhadap pemerintah kolonial yang kemungkinan besar dimotori oleh tokoh-tokoh komunis. Seorang nenek usia 85-an menyanyikan lagulagu, yang dahulu sewaktu ia masih kecil seringkali di-kudang (dininabobokkan) oleh ibunya. Satu lagu perihal peristiwa 12 November 1926 tersebut, menjadi memori Peristiwa Bedewang, di mana warga Bedewang membunuh beberapa prajurit pemerintah kolonial, membakar kendaraan mereka (mobil), lantas melarikan diri mengosongkan desa. ${ }^{6}$ Temuan ini setidaknya menunjukkan bahwa sejak sebelum proklamasi kemerdekaan, komunisme bahkan dimungkinkan beserta bangunan organisasinya telah tumbuh dan berkembang di Banyuwangi.

Selain itu, di tahun 1951, lahir di Banyuwangi aliran kepercayaan "Pasti" (Pantja Setia), diinisiasi oleh seorang guru sekolah dan memusatkan pada kepercayaan bahwa "Lima Pilar" dari Pancasila seharusnya dimaknai sebagai "Lima Kesetiaan" (Pantja Setia), sebagai kewajiban religi. Maksudnya, sila ketuhanan memerlukan moralitas, nasionalisme menawarkan pengerahan energi, ketangkasan, dan kerja keras; demokrasi ditafsiri bahwa seseorang harus mengedepankan kesabaran dan senantiasa mencari jalan kompromi dengan pihak yang lain; keadilan sosial bermakna kewajiban berderma alih-alih mencari kekayaan untuk diri sendiri; sedangkan kemanusiaan secara mendasar dimaknai sebagai tjintah asih. "Pasti" tidak memiliki ritual formal, kecuali ibadah individu, serta tidak memiliki memiliki struktur organisasi bagi para pengikutnya, selain semata-mata hanya berkumpul di rumah seorang anggota guna berdiskusi, ini pun tidak periodik waktu dan tempatnya, tergantung kebutuhan. Dari Banyuwangi, Pasti menyebar ke arah timur menuju Pulau Bali dan ke arah barat hingga Surabaya. Pada tahun 1961, "Pasti” memiliki pengikut sekitar 5000 orang. "Pasti” berupaya menjadi wadah sekte religi bagi marhaen. Namun, daya pikatnya terutama berhasil menarik kaum urban kelas menengah bawah, yang lantas menyebar di antara pegawai sipil (van Kroef, 1961, p. 20).

"Pasti” di Banyuwangi, "Permai” di Pare Kediri, "Persatuan Poso Sedjati” di Jawa Timur, "Agama Pantjasila" di Bandung, "Sapta Darma” di Sumatera Selatan, dan sekte religi lainnya, menurut Geertz (2011, 157-167) adalah sekte abangan modern yang di luar denominasi kekristenan mengekspresikan simbol-simbol seperti nativisme pra-Islam, oposisi antara adat dan hukum (agama Islam), pertentangan pendukung negara Pancasila dan pengusung negara Islam, dan tentunya, konflik abangan-santri. Selain itu, kelahiran berbagai sekte religi baru sejak tahun 1950-an, juga menyiratkan indikasi modernisasi pada kaum abangan, bahwa sekte religi yang terorganisasi ini ialah wujud budaya urban pada masa petani, atau sebaliknya, aspirasi petani yang terwadahi dalam kultur kota. Pada pertengahan tahun 1956, Biro Urusan Agama di Yogyakarta mengumumkan bahwa terdapat 63 sekte religi di seluruh 
Pulau Jawa, yang berlainan dengan penganut Islam, Katolik Roma, dan pelbagai denominasi Kristen Protestan; di mana 35 berada di Jawa Tengah, 22 di Jawa Barat, dan 6 di Jawa Timur. Pada akhir 1959, juru bicara Biro Urusan Agama Jawa Timur menyatakan bahwa sekitar 100 sekte religi telah berkembang di Jawa Timur, (van Kroef, 1961, p. 18).

Golongan Islam yang ada di Banyuwangi, secara umum didominasi oleh Islam tradisional yang dicirikan dengan kepemimpinan seorang kiai sebagai ulamanya, dan dapat dikatakan terwakili oleh Nahdlatul Ulama. Geertz (2013, 241) mengungkapkan, bahwa hingga berdirinya Nahdlatul Ulama pada 1926, ulama tidak pernah terorganisasi. Realitas ini setidaknya tercermin dalam sebuah surat ancaman yang dialamatkan kepada pendiri Muhammadiyah, setelah kedatangannya ke Banyuwangi. ${ }^{7}$ Sekembalinya dari Banyuwangi, berdasarkan riset (Idris, 1975, p. 63) tentang kehidupan K.H Ahmad Dahlan, beliau menerima surat ancaman pembunuhan, kepada dirinya dan istrinya. Djarnawi Hadikusuma dalam tesisnya $(1992,12)$ mengungkapkan, bahwa surat ancaman tersebut dilayangkan agar KH. Ahmad Dahlan membatalkan rencana pengajian yang hendak diadakan di Banyuwangi (Djainuri, 1992, p. 19). Kekerasan non-fisik anti-Muhammadiyah kembali terjadi di Banyuwangi setelah Presiden Abdurrahman Wahid dimakzulkan oleh Parlemen yang mana Amien Rais menjadi ketuanya. Rumah-rumah pengurus dan anggota Muhammadiyah diberi tanda silang dengan cat warna merah (Komunitas Informasi Terbuka, 2015). Golongan "Islam modern" dalam jumlah tidak besar, yang direpresentasikan dalam organisasi seperti Muhammadiyah, Masyumi, atau Al-Khairiyah, hadir dan berkembang di daerah-daerah kantung wong kulonan, seperti di pusat kecamatan Genteng, Kota Banyuwangi, Rogojampi, dan Srono. Di Genteng misalnya, Muhammadiyah didirikan oleh pendatang dari daerah Yogyakarta. ${ }^{8}$ Sementara organisasi Al-Khairiyah dan Al-Irsyad yang tampaknya eksklusif bagi orang-orang keturunan Arab, berkembang di Kota Banyuwangi dan Srono. ${ }^{9}$ Ditemukan pula keterangan bahwa salah satu dari tujuh organisasi yang mula-mula bergabung dalam MIAI adalah Hidayatul Islamiyah Banyuwangi, yang kemudian ditetapkan sebagai anggota luar biasa (Sya’roni, 1998, p. 56).

Masyumi lokal Banyuwangi sebagai organisasi sosial-religius maupun partai politik yang memiliki dua jenis keanggotaan, anggota kolektif (organisasi Islam, yakni NU, Muhammadiyah, PUI, dan PUII) dan anggota individual, relatif merupakan cerminan dari gejolak perpolitikan yang terjadi di tingkat nasional, paling tidak dilihat dari sudut pandang kaum Islam tradisional. Bahwa salah satu sumber dari banyak kekecewaan para pemimpin NU adalah karena para anggota individual tanpa massa pendukung diberikan posisi yang sama pentingnya dengan anggota kolektif. Tidak imbangnya antara jumlah orang NU yang duduk di kepengurusan dan kelompok lainnya diperburuk oleh penurunan status Majelis Syuro, bagian partai di mana NU terwakili dengan baik. Ketika fungsinya diturunkan dari badan legislatif menjadi hanya badan penasihat, para pemimpin NU kehilangan seluruh 
kekuatannya dalam proses pengambilan keputusan di dalam partai, bahkan dalam masalahmasalah kepentingan keagamaan, (van Bruinessen (van Bruinessen, 1994, p. 66).

Keputusan Konfrensi Partai Masyumi Cabang Banyuwangi tanggal 28 Juli 1952, di antaranya menghasilkan reformasi pengurus, di mana K.H. Harun Abdullah duduk sebagai Madjelis Sjuro (Pewarta Soerabaja, 1952), jabatan yang pernah diemban oleh K.H. Abdul Manan Berasan. Keluarnya Nahdlatul Ulama dari Masyumi sebagai hasil dari keputusan Muktamar NU di Palembang, selain dari kekecewaan penurunan fungsi legislasi Dewan Sjuro tersebut, juga disebabkan kejadian lain seperti jatah menteri agama yang oleh Perdana Menteri Wilopo tidak diberikan kepada calon NU melainkan justru memilih Faqih Usman dari Muhammadiyah, (van Bruinessen, 1994, p. 95). Maka, ketika Nahdlatul Ulama menjadi partai mandiri, keredupan Masyumi seakan sudah dapat diprediksikan. ${ }^{10}$ K.H. Harun kemudian mengundurkan diri dari posisinya sebagai Ketua Madjelis Sjuro Masjumi, dan pada pemilu 1955 terpilih menjadi perwakilan partai NU dalam Dewan Konstituante.

\section{Pesantren di Banyuwangi}

Para elit agama Islam di Banyuwangi adalah para pendatang atau keturunan kesekian dari para migran. Eviden yang memperkuat asumsi ini, di antaranya adalah bahwa sebagian pendiri pesantren tua di wilayah ini, dilahirkan di luar Banyuwangi. Kiai Haji Abdul Mannan (1870-1979), pendiri Pondok Pesantren Minhajut Thullab Sumberberas Muncar Banyuwangi (berdiri 1930) lahir di Desa Grampang Kabupaten Kediri ${ }^{11}$. Beliau adalah putra kedua dari pasangan Kiai Haji Moh. Ilyas yang berasal dari Banten dan Umi Kultsum yang berasal dari Jatirejo Kandangan Kediri (Ibid). Kiai Haji Mukhtar Syafaat (1919-1991), pendiri Pesantren Darussalam Blokagung Banyuwangi (berdiri 1951), saat ini pesantren terbesar di Banyuwangi, dilahirkan di Desa Ploso Lor, Plosoklaten, Kabupaten Kediri. Kiai Haji Askandar (19011967), pendiri Pondok Pesantren Mambaul Ulum Berasan Muncar Banyuwangi (berdiri 1930) lahir di Desa Sumber Dukuh, Gampeng Rejo, Kediri (Rofiq, 2014, p. 31). Contohcontoh ini, sesungguhnya adalah karakter umum pendirian pesantren di Jawa. Di mana para pendiri pesantren tidak berasal dari daerah setempat, seperti Kiai Haji Syamsul Arifin, pendiri Pesantren Sukorejo Asembagus Situbondo yang berasal dari Pamekasan Madura; Kiai Manaf, pendiri Pesantren Lirboyo Kediri yang berasal dari Magelang, atau Kiai Shihah, pendiri Pesantren Tambakberas Jombang yang asli Rembang.

Realitas ini bahkan juga terekam dalam kelakar bahwa orang Osing, sebagai 'penduduk asli' Banyuwangi hanya bisa jadi "kiai langgar", tidak akan mampu menjadi seorang "kiai besar" ${ }^{12}$ Kemungkinan dari adanya ungkapan ini pertama, merupakan fakta sejarah yang terjadi berulang-ulang, ditemukan di banyak tempat dan banyak waktu (omnipresent), sehingga seolah-olah sudah menjadi hukum alam bagi kehidupan masyarakat Banyuwangi. 
Kedua, ungkapan tersebut merupakan memori berwujud stereotype yang sengaja dibuat untuk tujuan-tujuan tertentu, misalnya penguasaan "lahan bisnis pesantren" oleh para pendatang dengan tidak meninggalkan sejengkal pun celah bagi orang Osing.

Hasil observasi dan wawancara, bermuara pada kesimpulan bahwa pesantren yang mula-mula di Banyuwangi kira-kira didirikan pada akhir abad ke-19 dan awal abad ke20. Beberapa informan menyebutkan Pesantren Jalen Genteng. Pesantren tersebut kini sudah mati, yang diasuh Kiai Haji Abdul Basyar, sebagai salah satu pesantren sepuh. Kiai Haji Askandar, Kiai Haji Muktar Syafaat, dan Kiai Haji Abdul Manan adalah murid-murid dari Kiai Haji Abdul Basyar, di mana murid yang disebut terakhir diambil menantu. Selain itu, sosok Kyai Muhammad Khalil Bangkalan (w. 1925) yang lebih populer dengan sebutan Syaikhana Khalil Bangkalan, ulama paling berpengaruh pada akhir abad ke-19 dan awal abad ke-20, diriwayatkan pernah berguru ke Kiai Abdul Basyar, tepat sebelum Kiai Khalil berangkat ke Hijaz. ${ }^{13}$

Islamisasi Banyuwangi tidak se-linier wilayah Jawa atau kepulauan lain di Nusantara. Sentuhan para sufi, guru mistik, atau juru dakwah yang dengan beberapa pertimbangan cenderung melakukan sinkretisme dengan kebiasaan penduduk pribumi. Misalnya, menyembuhkan orang sakit dengan bacaan atau mantra berbahasa Arab, memodifikasi dan memaknai seni yang bercorak Hindu-Budha atau pagan dengan simbol-simbol Islam, dan seterusnya (Johns, 1961, pp. 10-23). Adapun paranormal atau dukun yang memasukkan kata-kata berbahasa Arab dalam rapalan mantra mereka, besar kemungkinan ialah warisan dari para pendatang, bukan sinkretisme lokal yang dikreasikan di Banyuwangi. ${ }^{14}$

Seni gandrung Banyuwangi menjadi 'lebih Islami', bahkan tidak menutup kemungkinan juga ragam seni pertunjukkan yang lain seperti tari seblang, seni musik angklung, kendang kempul, dan seni abangan lainnya, baru sejak awal Orde Baru. Para penari gandrung memasukkan nada yang terdengar Islami di dalam pertunjukan-pertunjukan mereka dan, dengan cara demikian, terbebas dari keberatan kaum religius: menyelamatkan kesenian mereka dari kepunahan dengan cara mengislamkannya (Anoegrajekti dalam Ricklefs 2013, 222).

Zamakhsyari Dhofier menggambarkan bahwa relasi guru dan murid antar ulama tradisional mewujud dalam tiga hal; genealogi intelektual, perkawinan, dan tarekat. Dua yang pertama, berkaitan dengan ukuran kapabilitas seorang ulama serta jaringan nasab atau keturunan, sedangkan yang terakhir berhubungan pada jalan (thariqah: jalan) ritual mistis dan esoteris (Dhofier, 2011). Selain ulama dan kiai, di Jawa juga dipergunakan istilahistilah untuk golongan otoritas keagamaan, namun terbatas pada orang tertentu, seperti syaikh, maulana, dan sunan; di mana penggunaan ketiganya biasanya untuk orang-orang sepuh, dan jarang sekali penggunaannya untuk generasi pasca kemerdekaan. Hingga awal 
abad ke-19, setidaknya terdapat dua tokoh yang seringkali disematkan gelar syaikh di depan namanya, yakni Syaikhana Muhammad Kholil (w.1925) dan Hadratus Syaikh Hasyim Asy'ari (w.1947); di mana makna syaikh di sini berarti guru (Mandhur, 1707, p. 2373). Kedua tokoh ini, merupakan ulama yang menjadi guru bagi sebagian besar ulama di tanah Jawa.

Genealogi intelektual, bagi ulama tradisional, di antaranya dibuktikan dengan sanad (Al-Bukhari, 2011), dalam hal ini bermakna rantai transmisi yang menghubungkan antara guru dan murid dalam satu pengajaran bidang ilmu atau karya tertentu. Dalam tradisi pesantren, mata rantai transmisi intelektual ini memiliki standar tertentu; bahwa dalam satu angkatan atau kurun waktu tertentu, terdapat ulama yang dianggap sah sebagai simpul mata rantai pada zamannya, sementara yang lainnya dianggap kurang sah atau diragukan (Dhofier, 2011). Seorang santri kelana yang sudah cakap bahkan telah memimpin pesantren, tidak jarang nyantri ke suatu pesantren tertentu, untuk mendapatkan sanad dari pengajar yang memilikinya, sebagaimana yang dilakukan Kiai Haji Mukhtar Syafaat. ${ }^{15}$ Kapabilitas, pertanggungjawaban intelektual, nilai keberkahan, bahkan pamor seorang ulama, turut ditentukan dari sanad yang dimilikinya, kecuali itu ada maqalah (perkataan anu) yang populer dan berlaku di dunia pesantren, bahwa barang siapa belajar tanpa guru, maka gurunya adalah setan. ${ }^{16}$

Kiai Munawir, pendiri Pesantren Krapyak di Yogyakarta misalnya, terkenal di Jawa sebagai sebagai seorang ulama yang paling kompeten dalam ilmu tajwid, aturan baku membaca Alquran di abad ke-20. Ia menelusuri sanad pengetahuan tajwidnya, hingga sampai ke Nabi Muhammad SAW. Ini berarti dua hal: pertama, bahwa Kiai Munawwir (w. 1942) adalah isnad (individu-individu yang disebut di dalam sanad) bagi sebagian besar guruguru pengajar Alquran di Nusantara, setelah paruh kedua abad ke-20. Kedua, kapabilitas, pertanggungjawaban intelektual, serta pamor seorang guru pengajar Alquran dianggap terpenuhi manakala ia memiliki sanad Kiai Munawwir. Idealnya, dari mata rantai sanad ini dapat ditelusuri relasi guru-murid sekaligus sejarah intelektual pesantren berikut jaringan ulamanya.

Syaikhana Khalil Bangkalan juga dapat ditempatkan sebagaimana Kiai Munawwir dalam sanad ilmu tajwid, tetapi pada transmisi intelektual karya ulama abad pertengahan. Misalnya Al-Fiyah Ibnu Malik (w. 1273), kajian ilmu gramatika bahasa Arab yang berwujud seribu (al-fiyah, Arab: seribu) bait nadham (semacam sajak berima yang tetap) yang populer diajarkan di pesantren-pesantren di Jawa (Pijper, 1992, p. 97). Ia memiliki sanad yang tidak terputus sampai kepada pengarangnya. ${ }^{17}$ Selain itu, buku panduan standar yang diajarkan di pesantren terutama sekali di bidang ilmu yurisprudensi hukum Islam (fiqh), baik yang ditulis oleh ulama Timur Tengah abad pertengahan, maupun oleh karangan ulama Nusantara, seperti Syaikh Nawawi Banten (1813-1897), Syaikh Mahfudz Tremas (1842-1920), dan ulama abad ke-19 lainnya (Azra, 1992) 
Perihal transmisi intelektual di Banyuwangi, sosok Kiai Haji Abdul Basyar yang berasal dari Cirebon dan lantas mendirikan pesantren di Stail Genteng, biasanya disebutkan untuk menyebut guru dari beberapa ulama Banyuwangi. Di antara murid-muridnya yang terkenal adalah Kiai Haji Abdul Manan, Kiai Haji Askandar, Kiai Haji Mukhtar Syafaat. Selain itu ada kuburan Datuk Ibrahim, yang menurut sejarawan lokal berasal dari Palembang. Namun, perannya dalam pengembangan Islam di Banyuwangi seorang pendiri pesantren, atau santri kelana yang meninggal di Banyuwangi, atau seorang penghulu di samping posisinya dalam mata rantai sanad, juga tidak jelas.

Pertalian pernikahan sesama keluarga ulama memang ditemukan, namun tidak seketat dan serumit sebagaimana yang digambarkan (Dhofier, 1980, pp. 47-58) yang bersifat endogami, hingga membentuk suatu bani (fam) serta jaringan keluarga elit Jombang; atau yang dipaparkan Horikoshi (1987) dengan memisahkan endogami-eksogami, serta peluang orang luar masuk dalam lingkaran keluarga. Kiai Haji Abdul Basyar adalah mertua Kiai Haji Abdul Mannan, di mana yang disebut terakhir mengambil Kiai Haji Askandar yang adalah teman selama nyantri sebagai menantu. Di sisi lain, hubungan perkawinan antar sesama kiai ini tidak begitu ketat pada keluarga Kiai Mukhtar Syafaat, karena nasab (faktor keturunan) tidak determinan dalam pembentukan ulama. Ia dinikahkan dengan Siti Maryam, putri seorang petani. Baru pada pernikahan keduanya, beliau menikah dengan Musyarofah, putri seorang kiai dari Tegalsari Gambiran. Penerus Pesantren Blokagung saat ini adalah Kiai Haji Hisyam Syafaat, alumni Pesantren Sarang Rembang, yang diambil menantu, dan bukan seorang putra kiai pengasuh pesantren. Putri dari Kiai Hisyam Syafaat, Nihayatul Wafiroh juga dinikahkan tidak dengan putra seorang kiai. ${ }^{18}$

Sementara hubungan genealogis intelektual, terutama pada pesantren sepuh berpengaruh, di sini adalah Pesantren Jalen Genteng yang sudah mati. Dahulu diasuh oleh Kiai Haji Abdul Basyar. Selain itu, adalah Pesantren Cemoro Balak Songgon, yang dahulu diasuh Kiai Haji Abdullah Faqih (1878-1953). Semasa hidup, Kiai Abdullah Faqih dijadikan rujukan atau tempat bertanya oleh sebagian ulama di Banyuwangi. ${ }^{19}$

\section{Kesimpulan}

Sebagai sebuah satuan wilayah yang menjadi sudut terdesaknya agama Hindu di tanah Jawa, lalu menjadi daerah perluasan kekuatan Islam yang penghabisan, demikian juga masuknya Islam yang beriringan dengan rekanan ekspansi kolonial Barat-pribumi; maka dapat disimpulkan bahwa babagan sejarah Banyuwangi tidak seragam dan linier dengan tahapan sejarah Jawa pada umumnya. Islamisasi Banyuwangi dalam arti luas, yang tidak hanya dimaknai sebatas konversi kredo keimanan melainkan meliputi pula proses penegakan ritus-ritus serta norma agama Islam melibatkan agen-agen penyebar misi dakwah yang kemudian diidentifikasi sebagai ulama. 
Tahap Islamisasi yang pada awalnya beriringan dengan proses pasifikasi dari kekuatan kolonial barat dan pribumi, kemudian dilanjutkan dengan kolonisasi para pendatang beragama Islam. Pembangunan prasarana transportasi oleh pemerintah kolonial serta pembukaan lahan perkebunan, selain menarik kedatangan para migran, juga menjadikan Banyuwangi sebagai destinasi bagi para santri kelana dari bagian Pulau Jawa sebelah barat. Para ulama Banyuwangi saat ini merupakan keturunan, yang puak moyangnya dilahirkan di luar Banyuwangi. Islam yang 'baru' saja ada di Banyuwangi ini memuat mata rantai genealogi intelektual yang disandarkan pada ulama-ulama abad ke XIX dan XX, khususnya dua syaikh: KH. Kholil Bangkalan dan KH. Hasyim Asyary Jombang.

\section{Referensi}

Al-Bukhari, A. A. M. bin I. (2011). Ensiklopedi Hadits Shahih al-Bukhari I (terj.). Jakarta: Almahira.

Anoegrajekti, C. N. (n.d.). “Kesenian Using: Resistensi Budaya Komunitas Pinggir”, dalam Kebijakan Kebudayaan di Masa Orde Baru. Jakarta.

Arifin, W. P. (1995). Babad Blambangan. Yogyakarta: Yayasan Bentang Budaya dan EFEO.

Arps, B. (2009). “Osing Kids and the Banners of Blambangan Ethnolinguistic Identity and the Regional Past as Ambient Themes in an East Javanese Town". Wacana, Vol. 11. No. 1.

Azra, A. (1992). "The Transmission of Islamic Reformism to Indonesia: Network of Middle Eastern and Malay-Indonesian Ulama in the Seventeeth and Eighteenth Centuries." Columbia University.

Beatty, A. (2004). Varieties of Javanese Religion. An Anthropological Account. Cambridge: Cambridge University Press.

Bolland, B. . (1982). The Struggle of Islam in Modern Indonesia. Leiden: The Hague Martinus Nijhoff.

de Graaf, H. J. dan T. G. T. P. (1989). Kerajaan-Kerajaan Islam Pertama di Jawa. Kajian Sejarah Politik Abad ke-15 dan ke-16. Jakarta: Pustaka Utama Grafiti.

Dhofier, Z. (1980). "Kinship and Marriage among the Javanese”. Indonesia, No. 29.

Dhofier, Z. (2011). Tradisi Pesantren Studi Pandangan Hidup Kyai dan Visinya Mengenai Masa Depan Indonesia. Jakarta: LP3ES.

Djainuri, A. (1992). “The Muhammadiyah Movement in Twentieth-Century Indonesia; A Socio-Religious Study.” McGill University.

Geertz, C. (1960). “The Javanese Kijaji: The Changing Role of Cultural Broker”, dalam Comparative Studies and Society and History, 2 No. 2.

Geertz, C. (1980). Agama Jawa: Abangan, Santri, Priyayi dalam Kebudayaan Jawa. Jakarta: Komunitas Bambu.

Hesselink, L. (2011). Healers on the Colonial Market. Native Doctors and Midwives in the Dutch East Indies. Leiden: KITLV Press. 
Idris, M. (1975). “Kiyai Haji Ahmad Dahlan, His Life and Thought.” Montreal: McGill University.

Johns, A. H. (1961). "Sufism as a category in Indonesian literature and History." Journal of Southeast Asia History, 2.

Komunitas Informasi Terbuka. (2015). "NU VS MUHAMMADIYAH.”

Mackie, J. A. C. (1993). “The East Java Economy: From Dualism to Balanced Development”, dalam Howard Dick. Balanced Development: East Java in the New Order. Singapore: Oxford University Press.

Mandhur, I. (1707). Kamus Lisan al-Arab. Kairo: Daar al-Maarif.

Margana, S. (2012). Ujung Timur Jawa, 1763-1813: Perebutan Hegemoni Blambangan. Yogyakarta: Pustaka Ifada.

Pewarta Soerabaja. (1952). "Putusan konprensi Masjumi Kab. Banjuwangi". Volkstelling 1930. Deel VIII Overzicht Voor Nederlandsch Indie. Batavia: Departement van Economische Zaken.

Pijper, G. F. (1992). Penelitian tentang Agama Islam di Indonesia. 1930-1950. Jakarta: UI Press.

Ricklefs, M. . (1993). War, Culture and Economy in Java. 1677-1726, Asian and European Imerialism ini the Early Kartasura Period. Allen \& Unwin. Honolulu: Hawai University Press.

Ricklefs, M. . (2001). A History of Modern Indonesia Since c.1200 (3rd Edition). Hampshire: Palgrave.

Rofiq, A. (2014). Tiga Kyai Khos Banyuwangi. Yogyakarta: LkiS.

Sya'roni, M. (1998). “The Masjilsul Islamil A'la Indonesia (MIAI): Its Socio-Religious and Political Activities (1937-1943).” Montreal: McGill University.

van Bruinessen, M. (1994). NU: Tradisi, Relasi-Relasi Kuasa, Pencarian Wacana Baru. Yogyakarta: LkiS.

van Kroef, J. M. (1961). van Kroef, Justus M.. "New Religious Sects in Java”. Far Eastern Survey, Vol. 30. N.

Wolbers, P. A. (1986). "Gandrung and Angklung from Banyuwangi; Remnants of a Past Shared with Bali". Asian Music (Autumn-Winter), Vol. 18.

Wolbers, P. A. (1992). "Maintaining Using Identity through Musical Performance; Seblang and Gandrung of Banyuwangi, East Java (Indonesia)" Disertasi. (-. University of Illinois at Urbana Champaign.

Wolf, E. R. (1956). "Aspect of Group Relations in a Complex Society: Mexico", dalam American Anthropologist, New Series. , No. 6, Vol. 58. 


\section{Sumber Lisan}

Gus Umar (64 tahun), pengasuh Pesantren Cemoro Balak Songgon. 24 April 2014.

Ikaningtyas (34 tahun) wartawan Tempo, 13 Januari 2014.

Imaduddin (71 tahun) putra tertua K.H. Irsjad Achjat, 2 Mei 2014.

Kiai Haji Abdul Fatah (65 tahun), dzurriyah (keluarga) Pesantren Tukang Kayu.

Kiai Haji Masykur Ali (60 tahun) Ketua Tanfidziyah NU Cab. Banyuwangi, 24 April 2014.

Nihayatul Wafiroh (35 tahun), ning (putri kiai) Kiai Haji Hisyam Syafaat., 24 April 2014.

Suhalik (52 tahun), Guru. 13 Januari 2014.

Sulhan (26), Wartawan koran lokal, Sabtu, 13 Januari 2014.

\section{Endnotes}

Penduduk Banyuwangi saat ini yang mayoritas beragama Islam tidak dapat secara bersamaan menerima kenyataan bahwa, pertama, mereka memiliki sejarah Kerajaan Blambangan sebagai identitas yang didaku, lengkap dengan tokoh-tokohnya yang legendaris; kedua, bahwa tokoh-tokoh tersebut, yakni Sayu Wiwit, Tawang Alun, dan Rempeg adalah penganut Hindu. Karena tidak ingin kehilangan sosok pahlawan yang mereka banggabanggakan - terutama jika dipertentangkan dengan Belanda yang kafir-maka terbentuklah memori baru, bahwa para pahlawan kebanggaan mereka adalah orang-orang yang beragama Islam. Misalnya sebutan Sayu, diperpanjang menjadi Sayyidina Ayu, walaupun gelar Sayu sesungguhnya adalah singkatan dari Mas Ayu. Kemudian petilasan Tawang Alun dianggap sebagai makam wali, Tawang Alun diyakini sebagai seorang raja beragama Islam, yang menyebarkan Islam di bumi Blambangan, dan seterusnya. (Observasi di reruntuhan Candi Macan Putih, 8 Mei 2014)

ii "Islam itu tidak melarang orang untuk kaya. Maka dulu kok orang-orang itu mau minta tanah, nyolong harta benda, ya ndak bisa dibenarkan.” Wawancara Imaduddin (71 tahun) putra tertua K.H. Irsjad Achjat, 2 Mei 2014.

iii Istilah ini merujuk pada gelar yang disematkan pada cerdik pandai perihal agama Islam di Nusantara, khususnya di Jawa. Derivasi istilahnya, baik berupa "kyai", "kiyai", "kijaji", atau "kiai", dalam penelitian ini diseragamkan menjadi kiai-kecuali dalam judul karya ilmiah-sesuai dengan entri dalam KBBI.

iv Aksi sepihak adalah tindakan yang dilancarkan oleh PKI sejak akhir 1963 untuk melaksanakan Undang-Undang Pokok Agraria 1960, yang isinya adalah redistribusi dan perubahan aturan kepemilikan tanah, terutama di Jawa. Sasaran dari kampanye ini adalah apa yang mereka sebut tujuh setan desa. Dari ketujuh golongan penyebutan ini, target paling besar adalah santri, yang adalah pendukung NU. Aksi ini menyebar hampir di seluruh pedesaan Jawa dan berkontribusi dalam motif pembantaian 1965-1966. Robert Cribb dan Audrey Kahin. Historical Dictionary of Indonesia. (Maryland: Scarecrow Press Inc. 2004), hlm. 324 (entri: Land Reform)

5 Januari 1965, terjadi aksi-aksi sepihak di 9 desa di Kecamatan Genteng, yang melibatkan sekurang-kurangnya 6.720 orang. Aksi sepihak juga terjadi di Kecamatan Srono, Cluring, Kabat, Gambiran, dan Glagah. Di beberapa desa, aksi sepihak tersebut 
berkembangmenjadi aksi pengrusakan atau pembakaran rumah, perampasan hasil tanaman, dan lain-lain. Lih. Laporan Pusat Studi Pedesaan dan Kawasan Universitas Gadjah Mada, hlm. 76.

vi Selain lagu 12 Nopember 1926, juga dilantunkan lagu "Darah Rakyat" (lirik terlampir). Saat diminta menyanyikan lagu "Maria Proletariat", si nenek mengaku sudah lupa. Sementara keterangan mengenai Peristiwa Bedewang, adalah rangkuman wawancara yang dilakukan oleh Suhalik, serta keterangan dari Yusup, (85 tahun) yang menegaskan bahwa pemimpin peristiwa Bedewang adalah Prang Mudro alias Suhud bin Samudro, yang menolak membayar pajak sebesar 27 ece. Narasi tandingan juga muncul bahwa pemimpin Peristiwa Bedewang adalah Kiai Abdulloh Faqih, pimpinan Pesantren Cemoro. Lih. Tri Asih Rahayu. "Peristiwa (Gerakan) Bedewang Kabupaten Banyuwangi", dalam Gema Blambangan., No. 064/1996., hlm. 44-45.

vii Keterangan perkembangan organisasi Muhammadiyah, hasil Wawancara Ikaningtyas (34 tahun) wartawan Tempo kontributor regional Banyuwangi, survey awal Sabtu, 13 Januari 2014.

viii Wawancara Imaduddin, 2 Mei 2014. Salah satu dari 25 organisasi peserta Konggres Umat Islam tahun 1938 di Solo adalah Al-Irsyad Banyuwangi. Lih. Mizan Sya'roni. "The Masjilsul Islamil A'la Indonesia (MIAI): Its Socio-Religious and Political Activities (19371943)”. Tesis. (Montreal: McGill University. 1998)., hlm. 56.

ix Kiai Manan, pendiri Pesantren Berasan pada awalnya masih memilih Masyumi ketika NU keluar dan jadi partai politik, walaupun tidak melarang-bahkan dikatakan menganjurkan-keluarga dan santrinya memilih NU. Namun kemudian diceritakan bahwa Kiai Manan-atas saran dari Kiai Tauzan Tulungagung-masuk ke NU. Anonim. Tanpa Tahun. Biografi Almarhum Almaghfurlah KH. Abdul Manan Pendiri PP. Minhajut Thullab Sumberberas Muncar Banyuwangi. Yayasan Minhajut Thullab-Muttaqien Press., hlm. 34. Keterangan dari Kiai Haji Anwar Iskandar Jamsaren Kediri (generasi ketiga Kiai Haji Abdul Manan) (Wawancara via BBM, kamis, 16 Oktober 2014-18.00 WIB).

x Anonim. ibid., hlm. 12. Keterangan dari Kiai Haji Anwar Iskandar Jamsaren Kediri (generasi ketiga Kiai Haji Abdul Manan), menyebutkan Doko Sragi Ngasem Kediri, dan bukannya Grampang (Wawancara via BBM, ibid.)

xi Wawancara, Gus Umar (64 tahun), pengasuh Pesantren Cemoro Balak Songgon. 24 April 2014.

xii Wawancara Kiai Haji Masykur Ali (60 tahun) Ketua Tanfidziyah NU Cab. Banyuwangi, 24 April 2014.

xiii Wawancara dengan Sulhan (26), Wartawan Lokal, Sabtu, 13 Januari 2014. Di antara bunyi mantra adalah "thila thili gaweane pèli, pulisi mlirik kaya pèliku, pulisi mlerōk kaya kōnthōlku, laa hawla walaa quwwata illa billah.” Khasiat mantra ini, bila di jalan raya naik sepeda motor tidak pakai helm dan ada polisi, tidak ditilang.

xiv Wawancara, Suhalik. 21 April 2014.

xv Man ta'allama bilaa syaikhin fa syaikhuhu syaithan. "Barang siapa belajar tanpa guru, maka gurunya adalah setan”. Wawancara Gus Umar, 24 April 2014.

xvi Lampiran Sanadu Nadlmi Al-Khulashoti Allatiy Isytaharot Bi Al-Fiyati Ibni Maliki. 
Koleksi pribadi Muhammad Amin, santri Pesantren Lirboyo Kediri.

xvii Wawancara Nihayatul Wafiroh (35 tahun), ning (putri kiai) Kiai Haji Hisyam Syafaat., 24 April 2014.

xviii Wawancara Kiai Haji Abdul Fatah (65 tahun), dzurriyah (keluarga) Pesantren Tukang Kayu. 